\title{
Cikkismertetés: Iskolai étkeztetési szakpolitika megvalósításának rendszerszintű vizsgálata Kanadában
}

\author{
Article review: System-Level investigation of School Food Policy \\ Implementation in Canada
}

Ismertető: $\quad$ Devosa Iván $\square$

Neumann János Egyetem, Pedagógusképző Kar, Egészségtudományi és

Egészségfejlesztési Kutatócsoport, Kecskemét

Ismertetett cikk: Mclsaac JLD, Spencer R, Stewart M, Penney T, Brushett S, \& Kirk SF. Understanding SystemLevel Intervention Points to Support School Food and Nutrition Policy Implementation in Nova Scotia, Canada. Int. J. Environ. Res. Public Health 2019, 16, 712; doi:10.3390/ijerph16050712

Beküldve: $\quad$ 2020. 04.21.

doi: $\quad$ 10.24365/ef.v61i2.592

Kulcsszavak: iskolai étkeztetési szakpolitika; komplex rendszerek; megvalósításelemzési keretrendszer

Keywords: school food policy; complex systems; Intervention Level Framework

\section{HÁTTÉR}

Az iskolai étkeztetési szakpolitikák (school food and nutrition policies, továbbiakban SFNP) végrehajtásának támogatása nemzetközi prioritást élvez a gyermekek és az ifjúság egészségesebb étkezésének ösztönzésére. Ezen szakpolitikák célja az egészséges táplálkozáshoz való méltányos hozzáférés, az erőforrások és az egészséges táplálkozás támogatása. Annak ellenére azonban, hogy elismerik az SFNP-k hatását, számos végrehajtást akadályozó tényező vált ismertté. A tanulmány készítői arra törekedtek, hogy az iskolai étkeztetésen belüli rendszerszintú beavatkozási pontokat feltárják, Új-Skóciában, Kanadában.

\section{MÓDSZER}

A kutatás a kanadai Új-Skóciában zajlott 2016-2017 folyamán 33 résztvevő bevonásával, köztük taná- rok, szülők, konyhai dolgozók, népegészségügyi szakemberek és nonprofit szervezetek munkatársai. A résztvevőkkel interjú készült, majd azok feldolgozásával kapott adatokból módosították a Megvalósításelemzési Keretrendszert (Intervention Level Framework, röviden ILF) és végül az ILF használatával három beavatkozási pontot azonosítottak az SFNP-n belül. Az interjúk átiratát először kódolták, majd csoportba sorolták és végül az ILF segítségével elemezték. [1. ábra]

Az ILF szintjei felfelé rendre nagyobb hatáspotenciállal bírnak, azaz minél magasabb szinten történik a beavatkozás, annál nagyobb hatás várható. [1. táblázat] Ennek segítségével jobban értelmezhetők a rendszerek szintjei közötti interakciók. A módosított modell alkalmazásának segítségével hatékonyabb szakpolitikai intézkedések hozhatók, amelyek az adott szakpolitika hatékony megvalósítását támogatják. 


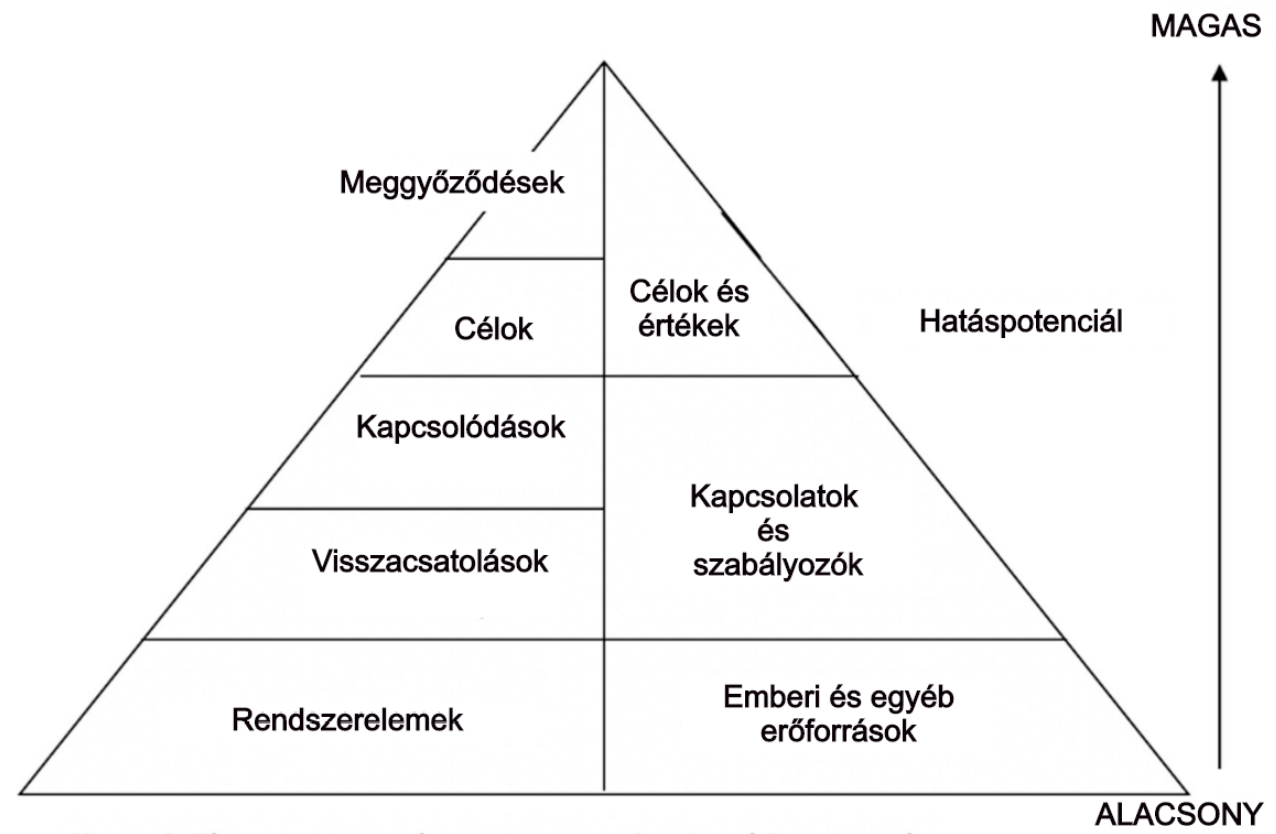

Forrás: saját szerkesztés az eredeti változat alapján

1. táblázat: A Megvalósitáselemzési Keretrendszer felépitése

Szintek

\begin{tabular}{|c|l}
\hline Meggyőződések & $\begin{array}{l}\text { Rendszer legmagasabb szintje: a rendszer céljainak, szabályainak és struktúráinak forrása. } \\
\text { Nehéz beavatkozni ezen a szinten, de nagyon hatékony lehet. }\end{array}$ \\
\hline \multicolumn{1}{|c|}{ Célok } & $\begin{array}{l}\text { A rendszer paradigmájának (meggyőződéseinek) megfelelő célok, amelyeket el kell érni a para- } \\
\text { digma átalakulásához. Az intézkedések ezen a szinten megváltoztathatják a teljes rendszer } \\
\text { céljait. }\end{array}$ \\
\hline Kapcsolódások & $\begin{array}{l}\text { Kapcsolatok a rendszerelemek és az alrendszerek között: az ezen a szinten végrehajtott intézke- } \\
\text { dések megváltoztatják a rendszer felépítését, a rendszerkapcsolatokat, vagy akár új elemeket is } \\
\text { létrehozhatnak. }\end{array}$ \\
\hline Visszacsatolások & $\begin{array}{l}\text { Lehetővé teszi a rendszer számára, hogy szabályozza magát azáltal, hogy információkat } \\
\text { szolgáltat a kimenetről: különböző tevékenységek visszahatása a cselekvő forráshoz. Ezen a } \\
\text { szinten megvalósított intézkedések új visszacsatolási hurkot hozhatnak létre vagy növelhetik } \\
\text { a már meglévő hurkok hatékonyságát. }\end{array}$ \\
\hline Rendszerelemek & $\begin{array}{l}\text { A rendszer alrendszerei, szereplői és fizikai elemei: a beavatkozás legegyszerúbb szintje. Ezen a } \\
\text { szinten általában számos intézkedésre van szükség a rendszerszintú változás eléréséhez. }\end{array}$
\end{tabular}

Forrás: Johnston et al. ábrájának magyar változata: Johnston, L.M.; Matteson, C.L.; Finegood, D.T. Systems Science and Obesity Policy: A Novel Framework for Analyzing and Rethinking Population-Level Planning.

\section{EREDMÉNYEK}

Az 1. ábra az iskolai étkeztetési rendszer szerkezeti elemeire és részeire vonatkozik, összhangban az
ILF-fel. A tanulmány részvevői: tanulók, családok, tanárok, igazgatók, a kávézóban dolgozók, az élelmiszer-forgalmazók, az iskolaszék, a kormány és a különféle külső érdekelt felek, például közösségi 
szervezetek és kiskereskedelmi vagy gyorséttermi üzletek.

Az ILF legalsó szintjén („Emberi és egyéb erőforrások”) úgy találták, hogy nem minden szereplő vonódik be az iskolával kapcsolatos egyeztetésekbe, az élelmezési politika végrehajtásába, vagy az ahhoz kapcsolódó konkrét felelősségek viselésébe. Az egyeztetések nagy része, a résztvevők az iskolai élelmezési rendszerek létrehozására és fenntartására gyakorolt feladatiról szólt.

A „Kapcsolatok és szabályzók” szintjén a résztvevők közötti interakciók, kommunikációs mechanizmusok magasabbak szintűek, az ebben résztvevő döntéshozók gyakran vitatták az erőforrásokat és azok hiányát: a legfőbb problémának a rendelkezésre álló anyagiak szűkösségét és az időkorlátot tartották. A tanulmány szerzői kiemelik, hogy egy kávézó alkalmazottja a következőt jegyezte meg: „Ha ilyen sok gyermeket szolgálsz ki, akkor valószínúleg nem készítheted a muffinjaid akármilyen alapanyagból. Olyannak kell lennie, amelyből az gyorsan elkészíthető". Ez szorosan kapcsolódik a humánerőforrás kapacitáshoz.

\section{KÖVETKEZTETÉSEK}

A tanulmány megállapításai szerint a fenti három probléma (anyagi erőforrás-, idő- és emberhiány) a következőkkel orvosolható: az egészséges iskolai étkezési környezet támogatása - ideértve a „jó gyakorlatok" megosztását - a költségvetés átdolgozása, eszközök biztosítása, folyamatos továbbképzések szervezése.

Mindezek eléréséhez rendszerszinten (ILF) kell cselekednie a felelősöknek, és amelyhez három beavatkozási pontot azonosítottak az iskolai étkeztetésre vonatkozó ILF-ben. Ezek támpontot jelentenek a döntéshozóknak tartományi szinten és akár más országokban is. A legmagasabb beavatkozási szint a "Célok és értékek”, amely lehetőséget kínál a szemléletváltásra az egészséges iskolai étkeztetésben. Ez tovább javítható az alacsonyabb szinten múködő „Kapcsolatok és szabályozók”, illetve az „Emberi és egyéb erőforrások” megértésével. Ezek a szintek - amelyekről a tanulmány szerzői megállapították, hogy egymással szorosan összefüggenek rávilágítanak az iskolai étkeztetés összetettségére, és arra is, hogy a beavatkozás legalacsonyabb szintjét képviselő „Emberi és egyéb erőforrások” mily nagy mértékben befolyásolják a teljes rendszer működését. A kutatás jelentősége, hogy hangsúlyozza a rendszer szereplőinek összehangolt együttmüködésének fontosságát, valamint a rendszer legmagasabb beavatkozási pontjain végrehajtott változtatás kiemelt értékét az egészséges iskolai élelmezés támogatásának folyamatában.

\section{TANULSÁGOK A HAZAI SZAKEMBEREK SZÁMÁRA}

A kanadai Új-Skóciában 2016-2017 folyamán lefolytatott kutatás eredményei Magyarországon is hasznosíthatóak, ugyanis az iskolai étkeztetésben az ott fennálló problémák (anyagi erőforrás-, idő- és emberhiány) nálunk is probléma. Ha a résztvevő felek érzik a jobb kommunikációt, munkájuk elismertségét, több pénzt juttatnak a döntéshozók a jobb minőségű és mennyiségű alapanyagok beszerzésére, nálunk is jelentősen javulhat az iskolai étkeztetés minősége, és csökkenne a „menzák” rossz megítélése. Ehhez a ILF alapján rendszer szintű beavatkozások szükségesek, azaz mindhárom szinten („Emberi és egyéb erőforrások”, „Kapcsolatok és szabályozók”, „Célok és értékek”) összehangoltan szükséges változtatni, ha tartós hatást kívánunk elérni.

\section{KÖSZÖNETNYILVÁNÍTÁS}

Köszönettel tartozunk a publikálás támogatásáért, amely az EFOP-3.6.1-16-2016-00006 „A kutatási potenciál fejlesztése és bővítése a Neumann János Egyetemen" pályázat keretében valósult meg. A projekt a Magyar Állam és az Európai Unió támogatásával, az Európai Szociális Alap társfinanszírozásával, a Széchenyi 2020 program keretében valósul meg. 